\title{
Lutas urbanas pelo direito à habitação em Lisboa em tempos de pandemia
}

\author{
Urban struggles for the right to housing \\ in Lisbon in times of pandemic
}

Luís Mendes [I]

\begin{abstract}
Resumo
Em Lisboa, durante o período de pandemia covid19, a ação dos movimentos sociais urbanos acirrou-se, capitalizando a visibilidade para o direito à habitação, como direito humano básico e imperativo incondicional de saúde pública, para cumprir os deveres de quarentena e isolamento social, impostos pelo Estado de Excepção. Descrevendo o processo de lutas urbanas, participação e contestação, e ganhos na moratória contra os despejos e pagamento dos alugueres, concluímos que os atores nessa luta urbana têm poder limitado sobre as mudanças que iniciam ou fazem um esforço para infligir, se não estiverem envolvidos em uma ação concertada e politicamente integrada, até porque as conquistas que obtêm são temporárias e excepcionais, à semelhança do próprio estado de emergência imposto pela covid19.
\end{abstract}

Palavras-chave: movimentos sociais urbanos; lutas urbanas; direito à habitação; covid19; Lisboa.

\begin{abstract}
In Lisbon, during the covid-19 pandemic period, the action of urban social movements was intensified, capitalizing on the visibility of the right to housing as a basic human right and an unconditional public health imperative to fulfill the duties of quarantine and social isolation imposed by the State of Exception. Describing the process of urban struggles, participation and contestation, as well as gains from the moratorium on evictions and rent payments, we conclude that the actors in this urban struggle have limited power over the changes they initiate, or make an effort to inflict, if they are not involved in a concerted and politically integrated action, not least because the achievements they obtain are temporary and exceptional, similar to the state of emergency imposed by covid-19.
\end{abstract}

Keywords: urban social movements; urban struggles; housing rights; covid-19; Lisbon. 


\section{Introdução}

É inegável que a cidade de Lisboa viveu, na década compreendida entre 2009 e 2019, um pico de projeção internacional enquanto destino turístico, ao mesmo tempo que o seu mercado de habitação adquiriu formatos de ativo financeiro e atraiu dinâmicas globais de procura e de investimento estrangeiro. Esse processo foi alavancado por programas governamentais e pela viragem neoliberal na política urbana, que fomentaram a atração de uma elite transnacional e favoreceram a financeirização do imobiliário e a reestruturação urbana na capital portuguesa (Mendes, 2016 e 2017; Nofre et al., 2018; Cócola Gant e Gago, 2019; Lestegás, Seixas e González, 2019; Sequera e Nofre, 2019). Assistiu-se a uma intensa gentrificação turística, mediante a transformação dos bairros populares e históricos da cidade centro em locais de consumo e turismo, pela expansão da função de recreação, lazer ou alojamento turístico/arrendamento de curta duração que substituiu gradualmente as funções tradicionais da habitação para uso permanente, arrendamento a longo prazo e o comércio local tradicional de proximidade, agravando tendências de desalojamento e segregação residencial (Mendes, 2017; Barata Salgueiro, Mendes e Guimarães, 2017; Gago, 2018; Gago e Cócola Gant, 2019). Os bairros do centro histórico, prosseguindo um processo de despovoamento que data de há 40 anos a esta parte, continuam a ser esvaziados da população que os ocupou durante décadas ou impede-se a população de baixo estatuto socioeconómico de aceder à habitação nessas áreas, colocando em risco a sustentabilidade social do centro histórico, à medida que parecem perder o tecido social e económico que Ihes conferia identidade, memória, enfim, a dita "autenticidade" de que se fala tanto e não se chega a um consenso sobre o que é; mas que, justamente, constitui recurso turístico (Wilson e Tallon, 2012; Barata Salgueiro, 2017; Pavel, 2016 e 2017; Cócola Gant, 2018; Baptista, Nofre e Jorge, 2018).

Fala-se bastante do fenómeno da turistificação, mas, a par desta, há que considerar as dinâmicas do complexo imobiliário-financeiro como sendo um eixo fundamental para a recuperação da economia urbana pós-crise capitalista no caso de Lisboa. Especificamente, foi a virada neoliberal dos sucessivos pacotes legislativos para uma reabilitação urbana mais pró-mercado, os programas Golden Visa, Residentes Não Habituais, as recentes Sociedades de Investimento e Gestão Imobiliária (Sigi), o Fundo Nacional de Reabilitação do Edificado (FNRE), a nova lei de arrendamento urbano de 2012, o novo regime fiscal dos Fundos de Investimento Imobiliário, a nova lei do alojamento local (turístico), a disponibilidade de um imenso parque habitacional devoluto e acumulador de um grande rent gap, além do forte crescimento da procura turística na cidade, que geraram distorções e mudanças significativas no mercado residencial, reforçando tensões especulativas. A remodelação de edifícios nos bairros históricos de Lisboa, com vista ao desenvolvimento massivo e desregulado do alojamento turístico e de produção de habitação de luxo ou, pelo menos, de alto standing, inacessível à maioria da população portuguesa, mas adaptada ao mercado imobiliário internacional e às novas procuras residenciais de um elite crescentemente transnacional (Mendes, 2017 e 2018a; Montezuma e McGarrigle, 2018; Pereira, 2018; Lestegás, 2019; Carvalho et al., 2019; Sequera e Nofre, 2019). 
0 desencadear da crise capitalista de 2008-2009 e o seu prolongamento por meia década seguinte agudizaram as desigualdades socioespaciais (Aalbers, 2012; Seixas et al., 2015; Alves, 2017), nomeadamente, em relação às distorções registadas no mercado de habitação das grandes cidades portuguesas, como Lisboa e Porto, com a produção de injustiça socioespacial associada ao reforço dos despejos, da segregação residencial e da exclusão territorial, por meio de uma aceleração da gentrificação, da especulação imobiliária e da financeirização da habitação. Essa conjuntura deu origem a uma onda de protestos sociais e de contestações que, por sua vez, dão visibilidade à questão do direito à cidade e à habitação, num movimento contra-hegemônico que denuncia as lógicas de mercantilização e financeirização no setor habitacional, de turistificação e de apropriação exclusivamente privada de outras comodidades de uso urbano coletivo e público (Mayer, 2010; Mayer, Thörn, C., Thörn, H., 2016; Colomb e Novy, 2016; Milano, Novelli e Cheer, 2019). Alguns desses protestos sociais e lutas urbanas têm dando origem à configuração de movimentos sociais urbanos (MSU), cuja ação se tem orientado, especialmente, para a afirmação da questão da habitação na agenda política e social portuguesa.

A situação de autêntico Estado de Exceção (Agamben, 2010, 2020; Sousa Santos, 2020) que se viveu em Portugal em virtude da expansão da pandemia covid19 e do acionamento do estado de emergência, com a obrigatoriedade de isolamento social e quarentena, bem como as limitações à liberdade de circulação e de atividades económicas acirraram a discussão em torno do direito à habitação em Portugal. Os coletivos e associações de defesa desse direito souberam capitalizá-lo como direito humano, pela dificuldade de acesso à habitação em condições de habitabilidade digna e que permitiam o isolamento requerido pelas autoridades políticas de saúde, catapultando esse assunto para o topo da agenda social e política. Multiplicaram-se protestos digitais, campanhas, abaixo-assinados, petições ou até ofícios e memorandos dirigidos às autoridades políticas com responsabilidade na matéria (Mendes, 2020).

O período da covid19 tem exposto as contradições e desigualdades de um modelo de recuperação económica da última década no pós-crise capitalista 2008-2009 muito assente nos pilares do investimento estrangeiro e da financeirização das dinâmicas do imobiliário e da turistificação do território, gerando um crescimento rápido, mas de pouca sustentabilidade ambiental, social e económica. A recuperação económica fez-se com base num modelo rentista, extractivista e predatório que gerou inúmeros fenómenos de acumulação por despossessão (Aalbers, 2008, 2016, 2017 e 2019; Harvey, 2010; Sassen, 2014; Rolnik, 2015). Ora, justamente, as dinâmicas de protesto social, reivindicação e lutas urbanas pré-covid revelam-se, agora, essenciais, de forma a capitalizar a aprendizagem e memória a coletiva, o capital social das redes criadas e o impacto que tiveram no colocar a problemática do direito à habitação na agenda pública e política nos últimos anos (Accornero et al., 2020; Mendes, 2020).

Uma situação de emergência global, como a que atravessamos, obriga os governos a mobilizarem recursos para capacitarem a resposta das autoridades de saúde e pôr em prática planos de recuperação económica e de proteção social excecional que protejam 
os cidadãos mais frágeis dos impactos da crise provocada pela pandemia. Isso permitiu que, agora, em tempos de pandemia covid19, a resposta do governo, do sistema partidário e da democracia representativa se fizesse com sentido de urgência, tendo, desde logo, suspendido os despejos e avançado com medidas temporárias e extraordinárias de garantir o direito à casa, ao abrigo, que possibilitassem o confinamento em período de quarentena.

Como estão os MSUs que se formaram em Lisboa na pré-covid, respondendo às crescentes e agravadas desigualdades no mercado imobiliário durante a atual pandemia? A reorganização das estratégias desses ativismos durante a covid19 permitiu que agora, em tempos da pandemia, a resposta do governo, do sistema partidário e da democracia representativa fosse realizada com um sentido de urgência?

Para responder a essas questões, além de uma revisão da literatura nacional e internacional sobre MSU e algumas intervenções e trabalhos recentes sobre covid19, a linha metodológica deste artigo é composta por métodos e técnicas qualitativos (entrevistas semiestruturadas a ativistas e análise crítica de conteúdo das mídias sociais e outras propagandas) que permitem uma macroanálise das várias leis que produziram a cidade de quarentena durante esse período de estado de emergência e uma interpretação do desempenho de várias associações e movimentos (o movimento Morar em Lisboa, a Associação Habita, o coletivo Stop Despejos e a Rede H), levando em consideração o trabalho de pesquisa-ação e de observação participante desenvolvido pelo autor como ativista nos últimos três anos.

\section{Espaços de contestação e emergência de novos movimentos sociais urbanos no período pré-covid}

A crise capitalista de 2008-2009 e o período de austeridade que se the seguiu em Portugal, pelo menos até 2014, com o consequente agudizar das desigualdades socioespaciais no espaço urbano têm vindo a dar origem a uma onda de protestos sociais e de manifestações que, por sua vez, dão visibilidade à questão do direito à cidade e à habitação (Mayer, 2010; Mayer, Thörn, C. e Thörn, H., 2016; Nel.lo, 2015; Mendes, 2018b), num movimento contra-hegemónico que denuncia as lógicas do urbanismo de austeridade, da mercantilização e financeirização no setor habitacional e de apropriação exclusivamente privada de outras comodidades de uso urbano coletivo e público (Tulumello, 2018; Seixas e Brito Guterres, 2018; Moura, 2019). Em face das contradições urbanas geradas pela omnipresença da crise económica e financeira, outra coisa não seria de esperar do que o recrudescimento dos MSUs, fazendo depender a capacidade transformadora desses movimentos da articulação com a luta de classes e com o processo de política urbana local daí resultante (Mendes, 2008), como aconteceu com os movimentos populares de luta por casa e pelo direito à cidade no pós-25 de Abril em Portugal.

(1973 e 1983) define lutas urbanas como práticas reivindicativas que tentam modificar ou alterar as contradições que atravessam a cidade capitalista. Quando existe a convergência dessas lutas com as lutas operárias, assiste-se 
ao aparecimento de MSU. Estes, também segundo o autor, são práticas específicas das lutas urbanas com capacidade para transformar a lógica urbana estruturalmente dominante (Pickvance, 2003). Para Castells, um MSU é um movimento coletivo de demanda que expressa de forma autônoma os interesses de algumas camadas populares que se dirigem ao Estado como um interlocutor privilegiado. Um movimento social nasce do encontro de uma certa combinação estrutural, que acumula várias contradições, com um certo tipo de organização. Quanto maior o número de contradições acumuladas, maior será o ônus social, logo, mais potencialmente mobilizador será também. Para muitos autores que se têm vindo a debruçar sobre essa problemática (ex: Castells, Touraine, etc.), um dos pressupostos estruturantes a reter a propósito dos MSUs é de que estes participam da capacidade transformadora do movimento de massas em virtude da correlação de forças que se estabelecem no seu seio. Sem essa articulação de ações, por exemplo, com o movimento operário - centro de gravidade das lutas históricas -, as lutas urbanas perderão todo o seu potencial transformador. Existe, assim, a necessidade de alargamento das lutas urbanas a toda uma multiplicidade de contradições urbanas que Ihe confiram legitimidade de organização. Tal organização só poderá processar-se na base do respeito e apoio mútuos, perante o valor próprio de cada campo de luta para os diferentes grupos de pressão implicados (Köhler e Wissen, 2003; Miller e Nicholls, 2013).

Esse aspeto parece escapar aos novos MSUs, embora em nada Ihes pareça abafar o potencial emancipatório e transformador. Os novos movimentos sociais que têm surgido nas sociedades ocidentais, a partir dos anos 1980, caracterizam-se por uma natureza heterogénea; carácter localizado, disperso e efémero; radicalismo e espetacularidade das ações; e ausência de ideologias programáticas. 0 esbatimento dos conflitos de base classista (sobretudo o operário), a fragmentação e a precarização da relação salarial e da situação perante o emprego, a massificação e simultânea individualização dos consumos e dos estilos de vida, a atomização e fragmentação dos comportamentos quotidianos, a ausência de partilha dos problemas/projetos coletivos e consequente desvanecimento da identidade coletiva e do sentido de partilha no seio da comunidade, todos esses fatores contribuem para que se experimente uma crescente perda de capacidade mobilizadora das tradicionais estruturas associativas (sindicais, partidárias, etc.) (Estanque, 1999; Miller, 2000).

Há que perceber o papel dos novos MSUs no combate e resistência ao processo de gentrificação e das possibilidades/oportunidades da sua afirmação na reforma da ordem urbana vigente. Embora esses novos MSUs sejam bastante autónomos em face das manipulações do político e da ideologia partidária da democracia representativa, a verdade é que deixam de ter uma base social realmente organizada. Os novos movimentos sociais situam-se fora da esfera do trabalho e da produção, afastando-se do ideal da luta operária, pelo que desenvolvem uma ação crítica e contestatária, dando enfoque, sobretudo, a um aspeto particular e específico das condições gerais de existência, ignorando a totalidade; caracterizam-se por uma desconfiança generalizada para com o Estado (partidos e políticos) - forte consciência crítica antipartidos; são, então, dominados por particularismos específicos, enfermando de um caráter periférico 
relativamente às contradições centrais entre capital e trabalho; exprimem uma nova cultura política, centrada nos valores do direito à diferença e na política de identidade, e não de classe social; não dispõem de uma articulação sólida com as diferentes frentes de luta, o que representa uma relativa fraqueza política (Sousa Santos, 1994, 2011; Estanque, 1999, 2014).

Atualmente, essa nova onda de protestos parece ter reavivado o debate teórico sobre a práxis dos MSUs e da ação coletiva em espaço público. Embora existam poucos estudos empíricos sobre essas manifestações e mobilizações de indignação pública em Portugal e sejam ainda mais escassas as análises comparativas com outros países, a verdade é que os acontecimentos da passada metade de década em Portugal parecem exigir uma atualização sobre a agenda de pesquisa dos fenómenos de protesto social, porque, ainda que a indignação não configure, por si, um movimento social urbano, é certamente um estado de espírito que pode ser catalisado para criar um. Os movimentos sociais pós-crise capitalista têm chamado a atenção para a academia: a descentralização relativa na sua organização, fazendo uso de apelos iniciados por redes digitais de forma rápida e predominantemente com recurso à distribuição mediática (Queirós et al., 2015; Fonseca, 2018); a complexa relação entre o sujeito individual e o movimento como identidade coletiva; uma composição social complexa dos atores desses movimentos na sua identidade multirreferencial, compósita e flexível; a luta política baseada nas ideias pouco ambiciosas no sentido de renovação total de um projeto de cariz nacionalista ou qualquer vocação para a tomada de decisão representativa, apelando para formas mais heterodoxas de organização política e de participação política e democrática, à margem das instituições; a internacionalização de movimentos territorializados e localizados, mas não necessariamente localistas; e, finalmente, um repertório/discurso tanto reativo - quando se pretende obter direitos já conquistados, mas subtraídos durante a crise económica como proativo - para conquistar novos direitos ou de luta para a efetiva implementação dos direitos já adotados, mas nunca efetivamente implementados (Bringel, 2015).

Para muitos na esquerda tradicional (os partidos políticos socialistas e comunistas e a maioria dos sindicatos), a interpretação da geografia histórica dos movimentos políticos de base urbana tem sido marcada por pressupostos políticos e táticos a priori que levaram à subestimação e incompreensão do potencial dos movimentos urbanos de base para provocar não só a mudança radical, mas também revolucionária. Os MSUs são vistos, muitas vezes, como, por definição, separados da (ou acessórios dessa) luta classista anticapitalista mais tradicional que tem as suas raízes na exploração e alienação do trabalho vivo na produção. Se os MSUs são considerados em tudo o resto, eles são normalmente interpretados tanto como meros desdobramentos ou fragmentos dessas lutas mais fundamentais. Compreender a política e potencial revolucionário de movimentos como os "indignados" em todo o sul da Europa, em 2011, e o "Occupy Wall Street" é um sério desafio (Harvey, 2012).

No caso concreto do combate à gentrificação, não se podem ignorar as políticas reguladoras e o controlo estatal, tanto em nível nacional como local, que continuam a ser um poderoso agente de controlo do mercado imobiliário e do solo urbano, bem como 
outras culturas locais de bairro ou resistências populares, para as quais são tributárias as dinâmicas associativas e as comissões de bairro (ex: associações de inquilinos versus de senhorios), que, assumindo dinâmicas de coletivo, fortalecem a sua inadaptação e bloqueio à lógica de mercado e impedem o avanço das fronteiras da gentrificação, da acumulação por espoliação ou despossessão (Harvey, 2010; Bradley, 2014; Butler e Athanasiou, 2013).

\section{As cidadanias participativas do movimento Morar em Lisboa}

Foi reconhecendo essa necessidade de luta unitária que várias associações e coletivos de Lisboa se uniram num grande MSU, o Morar em Lisboa (MEL), ${ }^{1}$ que é uma plataforma/ coletivo em que convergem ideias, vontades e dinâmicas de mais de 50 associações e 40 especialistas na questão urbana (arquitetura, sociologia, geografia, economia, urbanismo, etc.), visando a discussão e elaboração de propostas para uma política pública de habitação transparente e colaborativa, acompanhada e participada pelos cidadãos. Tem-se destacado no panorama português pela pressão que tem exercido junto do poder político (local e central), mas, também, pela sensibilização da sociedade civil, sendo já um movimento reconhecido por mediar a participação cidadã com as instituições da democracia representativa. Considera urgente e imprescindível colocar e manter na primeira linha da agenda política nacional o tema da Habitação e do Direito à Cidade. 0 movimento formou-se nos últimos meses de 2016 e apresentou-se, à sociedade portuguesa, em janeiro de 2017, com o lançamento de uma Carta Aberta pelo Direito à Habitação, que conta já com mais de 4800 assinaturas, número significativo para o contexto português, tendo, desde logo, uma expressão importante nos media portugueses e na sociedade civil, sobretudo em Lisboa. Teve como objetivo aproveitar a janela de oportunidade estratégica até outubro de 2017, em virtude da aproximação das eleições autárquicas, pois perceberam que era um momento relevante para pressionar o poder político central e local para a temática do direito à habitação, uma vez que a classe política estava mais suscetível de acolher as demandas dos cidadãos eleitores. O MEL atua pelo direito à habitação em Lisboa, embora esteja aberto a trabalho em rede, com outras cidades e territórios nacionais e internacionais.

As suas ações mais importantes e impactantes relacionam-se com a participação em audições parlamentares; reuniões com os políticos de todos os partidos e representantes em vários órgãos (Câmara Municipal, Junta de Freguesia, Assembleia da República) e organizações; informação aos media elaboração de pareceres relativamente a políticas; organização de debates, por exemplo, o que fizeram com os candidatos às eleições para a Câmara Municipal de Lisboa; reúnem e apoiam estudantes e investigadores; falam frequentemente com vários órgãos de comunicação social, nacionais e internacionais; participam em festivais, desfiles, exposições, manifestações e outras demonstrações públicas. Desde 2016, o MEL produz vários relatórios técnicos e pareceres para as autoridades políticas e desenvolve regularmente debates mensais sobre os tópicos de turismo, habitação, gentrificação e especulação imobiliária e políticas habitacionais, envolvendo toda a sociedade civil. 0 grande objetivo é alertar a consciência cidadã 
e a opinião pública para a crise da habitação em Lisboa (Mendes, 2018b e 2020; Malet, Gago, Cócola-Gant, 2018; Seixas, Tulumello e Allegretti, 2019).

Essa plataforma e outros movimentos habitacionais mais específicos também tiveram sucesso em impulsionar a ação de políticos preocupados com a crise habitacional. 0 MEL defende mais investimentos públicos em habitação, a reversão da neoliberalização dos preços e contratos de aluguéis, portanto, revogação da Lei do Arrendamento aprovada em 2012, o fim das isenções fiscais para fundos de investimento imobiliário, a abolição de esquemas que atraem investimento estrangeiro e favorecem a financeirização da habitação, tais como os vistos gold ou o regime dos residentes não habituais; defendem a regulação do turismo e do alojamento turístico de curta-duração, o típico airbnb, que em Portugal designamos de Alojamento Local.

O MEL considera indispensável a adoção urgente de uma política nacional e municipal de habitação que favoreça e dinamize o arrendamento, público e privado, com direitos e deveres, com segurança e estabilidade; incentive a colocação no mercado de propriedades devolutas (incluindo o património do Estado e dos municípios); estabeleça parcerias diversas com os setores privado e social; crie mecanismos de controlo das rendas através de uma política fiscal adequada, tendo em conta a função social do arrendamento; e dificulte e impeça os despejos sem assegurar o realojamento dos residentes.

O MEL defende e reivindica que, no nível do arrendamento, todos os contratos celebrados antes de 1990 devem manter-se em vigor independentemente da idade ou do grau de deficiência dos inquilinos, uma vez que foram livremente celebrados mediante o quadro legal existente ao tempo da sua celebração. Reivindica, também, e como regra, a renovação dos contratos celebrados, independentemente dos prazos, para dar estabilidade e credibilidade ao arrendamento e responsabilidade social à propriedade.

O MEL não processa queixas individuais, contudo recebe, semanalmente, várias denúncias e testemunhos de inquilinos e outros cidadãos que se encontram em situação de despejo ou prestes a serem despejados. Informam os residentes a não saírem das suas casas, a resistirem, a nunca assinarem documentação que não percebam, sem aconselhamento jurídico, a dirigirem-se à Associação dos Inquilinos Lisbonenses, Junta de Freguesia ou outros coletivos que os possam informar e auxiliar convenientemente. Quando os autorizam, divulgam os testemunhos em campanhas, o que é raro, pois o despejo envolve muita vergonha social, daí a sua invisibilidade.

O MEL iniciou, desde o verão do ano de 2017, um trabalho em rede com outros movimentos e associações de outras cidades afetadas pela turistificação (Barcelona, Veneza, Palma de Maiorca, entre outras) através da assinatura de um manifesto da Rede SET (Sul da Europa perante a Turistificação). Esse manifesto, sobretudo de cidades do sul da Europa, acusa que há uma enorme redução na oferta de moradias ou um aumento exponencial no êxodo de moradores com menor renda e recursos, principalmente nos centros históricos. Tal situação resulta em uma grande especulação imobiliária no decorrer da recente crise de 2008/2012, a partir da qual a panaceia do crescimento da indústria do turismo começa a desviar milhares de habitações de uso permanente para a função de alojamento turístico 
e hoteleiro. Por isso, em muitas cidades, está-se vendo e vivendo diversos movimentos de denúncia, de mobilização e de resistência dos cidadãos aos processos de turistificação que nelas estão ocorrendo. Entidades e grupos de ativistas e moradores dessas cidades vêm se reunindo em diferentes eventos, há pelo menos dois anos, para compartilhar e trocar experiências e conhecimentos, bem como para se unirem nas lutas e ganharem escala e massa crítica junto dos poderes políticos locais e nacionais. Diante dos conflitos que surgem com a gentrificação pelo turismo e com a especulação imobiliária, a população local tende a se organizar para defender seus direitos sociais, especialmente o direito à moradia digna e acessível e o direito à cidade. 0 trabalho coletivo que estão realizando nessas cidades geralmente começa com a visibilidade desses conflitos e a consciência deles, a crítica do modelo e a denúncia de suas consequências, e continua com a proposta de alternativas a ele. Exemplos destes últimos são ideias como o estabelecimento de limites à turistificação, adoção de políticas de preços diferenciados para uma habitação acessível, a desturistificação da economia da cidade, acompanhado por políticas de promoção de outras economias justas social e ambientalmente, argumentários semelhantes a outros movimentos europeus e no mundo (Colomb e Novy, 2016; Hughes, 2018; Mansilla, 2018; Sequera e Nofre, 2018; Pavel, 2020).

\section{As lutas de base da Associação Habita e do coletivo Stop Despejos}

Também orientado para o Direito à Cidade e à Habitação, e integrando o MEL, surgiu o coletivo Habita ${ }^{2}$ - Coletivo pelo Direito à Habitação e à Cidade. Embora constituído como Associação em 2014, sua atividade já existia há mais de uma década, desde 2009. Trata-se de um coletivo animado pela defesa que luta pela concretização desses direitos fundamentais, essenciais à vida humana, inscritos na legislação nacional e internacional, em particular aos relativos ao Artigo 65ㅇ sobre o direito à habitação e planeamento urbano, tal como se encontram dispostos na Constituição da República Portuguesa. Esse coletivo pertence a várias redes internacionais e congrega ativistas com experiência de trabalho de vários anos nessa área e que, ao longo do tempo, desenvolveram um diálogo com organizações e com entidades governamentais em várias instâncias, batendo-se pela dignidade humana e pelos direitos fundamentais no plano da produção e apropriação da cidade.

Na sua declaração de princípios, o coletivo Habita defende que todas as pessoas têm direito a uma habitação condigna. Este é um direito humano fundamental para a vivência de todos os direitos económicos, sociais, culturais, assim como cívicos e políticos, tendo por isso de ser respeitado e tratado de forma integrada com os outros direitos. Para além disso, a habitação é um direito reconhecido pela Declaração Universal dos Direitos Humanos, pelo Pacto Internacional de Direitos Económicos, Sociais e Culturais e pela Constituição da República Portuguesa: a) defende que todas as pessoas têm direito à cidade, igual acesso e usufruto aos seus vários espaços sociais e participação ativa no seu processo de produção e apropriação. 0 direito à cidade está intimamente ligado ao direito à habitação e desafia os múltiplos processos de segregação, precarização, discriminação, vulnerabilidade e expulsão que limitam o direito à habitação, assim 
como aos serviços, equipamentos e espaços coletivos das nossas cidades; b) defende que a habitação e o urbanismo devem ser parte de uma política pública verdadeiramente participada e que combata todas as formas de especulação imobiliária; c) luta contra a habitação encarada como um negócio/mercadoria que exclui as pessoas mais vulneráveis, que expulsa das suas casas e dos seus lugares quem não pode pagar os preços inflacionados e especulativos que, ao longo de décadas, favoreceram os sectores imobiliário e bancário; d) reivindica uma habitação compatível com os rendimentos das pessoas, adequada e integrada na cidade, com acesso a mobilidade, cultura, equipamentos e serviços; e) luta pela defesa dos direitos à habitação e à cidade, procurando potenciar a auto-organização e consciencialização das pessoas e a formação de ativistas. Esse coletivo combina de forma coerente o estudo e a reflexão das causas profundas que limitam o direito à habitação e à cidade com intervenção direta, denúncia, pressão política e pública para mudar sistemas, legislação e políticas, apoiando lutas e trabalhando pela formulação de propostas políticas.

Com uma dinâmica próxima à da Associação Habita, surgiu o coletivo Stop Despejos. Este é um coletivo em luta pelo fim dos despejos, pela defesa do direito à habitação e pela construção coletiva, inclusiva e mais justa das nossas cidades. Nesse contexto, apresenta-se como uma ferramenta de luta e de resistência "à onda de especulação financeira imobiliária e às políticas neoliberais que regem as cidades, privatizam o espaço público, atacam as nossas vidas, ameaçam e atropelam direitos fundamentais." ${ }^{3}$ Defende o direito à habitação digna para todos, o direito à cidade e à permanência de cada em seu bairro.
Procura juntar as lutas de todos os que estão em situação de despejo, ou de habitação precária, defendendo a criação de redes de solidariedade e a construção ativa e participada de alternativas de curto, médio e longo prazo. Como moradores e/ou apoiantes da luta por uma habitação digna e pelo direito à cidade, apresenta-se como um coletivo solidário, entendendo que a questão da habitação é um problema social, político e económico. Constitui-se enquanto plataforma de encontro e espaço de convergência de indivíduos, coletivos e movimentos em luta pelo direito a uma habitação digna e por uma cidade inclusiva e mais justa. Demonstra alianças com movimentos de base feministas, antirracistas, antifascistas e anticapitalistas, com os quais admite partilhar formas de ver o mundo e de lutar por outro melhor. O Stop Despejos é um coletivo horizontal, pois não existem hierarquias no interior do movimento, e as decisões são tomadas em assembleia. É também apartidário, pois não pertence nem apoia nenhum partido político; autofinanciado, pois, ao contrário de outras associações ou organizações não governamentais, não aceita subvenções ou qualquer tipo de apoio do Estado, mantendo-se independente financeiramente e autónomo, até porque não depende de nenhuma outra organização, igualmente.

O coletivo Stop Despejos é animado por uma filosofia de produção, apropriação e intervenção de cidade que prima pelo valor de uso, do coletivismo e da maioria social. Reclama o direito à construção coletiva dos espaços onde se vive, o direito ao espaço público, o fim da precariedade e da crise no acesso à habitação. "Num país onde se privilegiam o lucro imobiliário e as leis desrespeitam o direito a uma vida e habitação dignas, é legítima 
e necessária a desobediência." ${ }^{4}$ Por isso, para além de campanhas de comunicação e reivindicação, praticam a ação direta e apoiam a ocupação e a obstrução dos despejos, promovendo atividades de desobediência civil.

Como principais vitórias, o coletivo conta com os episódios da rua dos Lagares e o caso do prédio Santos Lima, que aqui brevemente se descrevem. ${ }^{5}$ No primeiro caso, dezasseis famílias residentes na rua dos Lagares, no bairro histórico da Mouraria, centro de Lisboa, receberam carta de oposição à renovação do contrato e seriam despejadas entre o verão de 2017 e início de 2018. A luta, fortemente apoiada pelo coletivo Habita e pela Associação de População e Património de Alfama (APPA), iniciou-se quando as moradoras se organizaram para pedir apoio à Câmara Municipal de Lisboa ( $\mathrm{CML}$ ) que, dizem, nunca se mostrou disponível para encontrar soluções. Entretanto, e com o apoio do Habita, os habitantes começaram a organizar-se de outras formas, tendo intervindo em inúmeras vezes na Assembleia Municipal e nas reuniões de CML. Ergueram cartazes na fachada do prédio, exigiram soluções e criaram o slogan: "A Câmara tem Casas, a Câmara tem Solução". Organizaram o "Santo António Contra os Despejos", com direito a Romaria, e convocaram a cidade para apoiar essa causa. Como se estava em época eleitoral autárquica (eleições no poder local), a CML entendeu que deveria afinal assumir as suas responsabilidades, negociando com o proprietário a renovação de todos os contratos por cinco anos sem alterações na renda. As famílias resistiram e permaneceram nas suas casas e bairro, tornando-se o episódio da rua dos Lagares um símbolo de luta bem-sucedida contra o avanço das fronteiras da gentrificação e da financeirização, no centro histórico de Lisboa. O bairro da Mouraria tem sido um dos espaços mais representativos dos despejos e expulsões do centro da cidade, através dos aumentos brutais que se registaram nos valores dos preços de aluguer e transformação de habitações em apartamentos alocados ao alojamento turístico. Mas a luta continua, pois o contrato de arrendamento foi renovado apenas por mais cinco anos (até 2022). É muito provável que, no fim do contrato, as famílias tenham que lutar novamente pelo seu Direito à Habitação e a permanecer no bairro onde nasceram e sempre viveram.

Tem-se a noção de que essa vitória se relaciona intimamente com as espacialidades e temporalidades criadas pelo Habita, nomeadamente, as múltiplas estratégias criativas, de performance, apartidárias, mediáticas, mas também à janela de oportunidade estratégica criada pela proximidade das eleições autárquicas que pressionou o então executivo da CML a assumir essa bandeira no seu repertório político. Essa estratégia foi também amplificada pelo MEL e utilizada, quer na pressão política dos governantes locais e nacionais, quer na pressão mediática e sensibilização da sociedade civil e da opinião pública, lisboeta ou nacional.

O segundo caso muito mediatizado e exemplo de vitória por parte do Habita foi o de Santos Lima, um prédio antigo da classe operária em Marvila, na zona oriental de Lisboa, onde ainda residem algumas famílias, nomeadamente idosos. Porém, e apesar de habitado, o prédio foi vendido a um fundo imobiliário como "devoluto". Desde então, os moradores começaram a sofrer de bullying imobiliário e de pressões por parte dos novos senhorios de forma a que abandonassem as suas casas. Por bullying imobiliário deve entender-se toda a forma de pressão, assédio, intimidação 
ou violência psicológica, simbólica ou física que, de forma reiterada e sistemática, é praticada pelo senhorio, proprietário ou outro agente hegemónico do mundo imobiliário sobre o inquilinato, de forma a facilitar a saída do residente inquilino, obstáculo que é ao negócio imobiliário. Degradar intencionalmente o prédio, retirando as escadas de acesso, por exemplo, submeter os moradores a obras constantes, cortar eletricidade, gás e água, são algumas das técnicas usadas por proprietários no centro de Lisboa para forçar os inquilinos a saírem de casa - e, dessa forma, aplicar um preço de aluguer mais alto ao imóvel.

Precisamente, a pressão dos ativistas e de MSU junto dos fóruns políticos, com forte cobertura mediática, conseguiu que se promulgasse a lei $n$. 12/2019 que veio alterar 0 Novo Regime de Arrendamento Urbano de 2012 (NRAU), estabelecendo que é

proibido o assédio no arrendamento ou no subarrendamento, entendendo-se como tal qualquer comportamento ilegítimo do senhorio, de quem o represente ou de terceiro interessado na aquisição ou na comercialização do locado, que, com o objetivo de provocar a desocupação do mesmo, perturbe, constranja ou afete a dignidade do arrendatário, subarrendatário ou das pessoas que com estes residam legitimamente no locado, os sujeite a um ambiente intimidativo, hostil, degradante, perigoso, humilhante, desestabilizador ou ofensivo, ou impeça ou prejudique gravemente $o$ acesso e a fruição do locado. (Artigo 13.o da lei n. 12/2019) ${ }^{6}$

Com o apoio do Habita e do Stop Despejos, os moradores do Santos Lima resolveram resistir ao despejo. Deram várias e repetidas vezes o testemunho pela sua causa, falaram em reuniões de câmara, deram entrevistas e expuseram a situação ilegal de que estavam a ser vítimas, informando-se sobre os seus direitos. Uma longa resistência pacífica e de desobediência civil levou a que a CML interviesse favoravelmente, e os moradores ganharam não só o direito de permanecer nas suas casas, mas também o direito a melhorias no imóvel que se encontra bastante degradado. No entanto, também nesse caso, a luta continua: apesar da decisão da CML, até à data, não existem garantias de cumprimento dos senhorios relativamente às obras de melhoria do edifício. Este é um processo no qual o Habita confessa ser necessário continuar a estar atento de forma a garantir os direitos desses moradores.

\section{Biopolítica, crise pandémica covid19 e Estado de Emergência em Portugal}

Sousa Santos (2020) argumenta que a crise pandémica covid19 normalizou a exceção. Por outras palavras, a atual pandemia não é uma situação de crise claramente contraposta a uma situação de normalidade. Desde a década de 1980 que, à medida que o neoliberalismo se vem impondo como versão ideológica dominante do capitalismo que se sujeita mais e mais à lógica do setor financeiro, o mundo tem vivido em permanente estado de crise. As geografias da história do capitalismo de Harvey (2010) demonstram isso mesmo. Como diz Harvey mais recentemente (2010 e 2014), o capital esforça-se para produzir a paisagem geográfica favorável à sua própria reprodução e evolução posterior. A paisagem geográfica do 
capitalismo é, contudo, tornada perpetuamente instável por várias pressões técnicas, económicas, sociais e políticas que operam no mundo de variações imensamente variáveis. 0 capital deve, necessariamente, adaptar-se a esse mundo em constante evolução. Mas o capital também tem um papel fundamental na formação do mundo. A forma como a paisagem evolui e se organiza afeta a acumulação de capital, mas também as contradições do capital e do capitalismo se manifestam no espaço, no lugar e no tempo. A maneira independente em que a paisagem geográfica evolui desempenha um papel fundamental na formação da crise capitalista. Sem um desenvolvimento geográfico desigual e suas contradições, o capital teria ossificado, há muito tempo, e caído em desordem. Este é um meio fundamental pelo qual o capital se reinventa periodicamente. 0 capital deve ser capaz de resistir ao choque da destruição do velho e estar pronto para construir uma nova paisagem geográfica sobre as suas cinzas. É, como refere Harvey (2020), o "capitalismo de desastre" presente nessa crise pandémica, ao serviço da destruição criativa da paisagem e reestruturação urbana, como forma de resolver as suas contradições, permitindo a constante reprodução das desigualdades, per si, causa e consequência da produção capitalista do espaço e da sua própria manutenção.

Os excedentes de capital e de trabalho devem estar disponíveis para esse fim. 0 capital, por sua própria natureza, perpetuamente cria tais excedentes, muitas vezes sob a forma de desemprego em massa do trabalho e uma sobreacumulação de capital. Veja-se o desdobrar da crise pandêmica numa crise social e económica, com a produção de milhões de desempregados por todo o mundo, com o encerramento e paragem das atividades económicas e recuo dos direitos laborais. A absorção desses excedentes, por meio da expansão geográfica e da reorganização espacial, nomeadamente pela reestruturação urbana, ajuda a resolver o problema dos excedentes que não dispõem de oportunidades lucrativas de reprodução. A urbanização e o desenvolvimento regional tornam-se esferas autónomas da atividade capitalista, exigindo grandes investimentos (normalmente financiados pela dívida) que levam muitos anos para amadurecer. As crises são essenciais à reprodução do capitalismo. É, no curso da crise, que as instabilidades do capitalismo são confrontadas, remodeladas e reestruturadas para criar uma nova versão do que o capitalismo é e pode ser. E isto através do espaço urbano que, por via da gentrificação, da especulação imobiliária ou da financeirização da habitação, reproduz desigualdades socioespaciais e segregação residencial, através de uma produção especulativa do lugar, estratégias de um urbanismo crescentemente neoliberal, que se afiguram como meio e condição essencial para uma geografia (de reprodução) do capitalismo financeirizado transnacional.

E o Estado de Exceção tem sido uma das formações de Estado Capitalista que, desde o nascimento da ideologia neoliberal nos anos 1970, tem apoiado a destruição criativa do capitalismo, que, através das lentes da Biopolítica de Foucault (2010a), revela-se uma arte de governamentalidade constante nas economias e sociedades contemporâneas, ganhando maior expressão no presente em face das medidas de confinamento e quarentena tomadas recentemente durante a crise da covid19, essenciais para a manutenção da saúde pública, impondo um código do "governo de si e dos outros". Bismarck (2020, s/p) defende o facto de a acumulação de capital 
(numa economia financeirizada como a vigente) situar-se não apenas na relação capital-trabalho, mas no terreno da própria vida (da reprodução biológica e social), o que ganha nova amplitude de forma distópica com a eclosão da crise pandémica:

Neste sentido, aquilo que está em causa não é simplesmente fazer da saúde ou da habitação um negócio, mas sim fazer do corpo, nas suas necessidades básicas e vitais, na sua existência nua, uma função fundamental da expansão da finança. Se podemos falar de uma financeirização da vida é porque o corpo foi capturado por uma miríade de instrumentos técnico-financeiros que o administram de acordo com as necessidades do capital, convertendo-o num factor de rentabilidade permanente dos circuitos abstractos e globais da finança. [...] Esta pandemia demonstra como as "políticas de fronteira" se deslocaram da escala do território para o "nível do corpo individual", é porque esse corpo é aquilo que deve ser a todo o custo protegido, salvaguardado e, sobretudo, vigiado; é porque ele é o centro de todos esses processos de extracção de mais-valia, de acumulação de capital e, finalmente, de despossessão. Digamos que essa vigilância corresponde necessariamente ao grau de produtividade económica e de reprodutibilidade financeira do corpo, indexando-o a um valor político e económico directamente contabilizável. E essa é também a razão pela qual esse corpo e essa vida estão, hoje, como nunca, sob o perigo de serem sacrificados, descartados como improdutivos (tal como a crise do subprime, em 2008, descartou desde o início a população negra pobre dos EUA, apanhada nas malhas do endividamento). [...] Se há algo que esta epidemia tem revelado de forma paradigmática é a extensão absoluta desse princípio da privatização da vida, da privatização do corpo, que o capitalismo e o neoliberalismo levam hoje até às últimas consequências: a conversão da vida, em todos os seus gestos, em todas as suas funções, em todas as suas necessidades básicas, vitais e fundamentais, numa função da rentabilidade do capital financeiro.

Logo no irromper da crise pandémica, Agamben (2020) insurgiu-se contra o perigo da emergência de um Estado de Exceção. O Estado, ao tomar medidas de vigilância e de restrição da mobilidade e das liberdades sociais, económicas e de resistência, sob o pretexto de combater a pandemia, adquiriria poderes excessivos que poriam em causa a própria democracia. Atento à situação atual, Agamben defende que a crise pandmica covid19 atesta a crescente tendência de usar o estado de exceção como paradigma normal de governo contemporâneo ao serviço do neoliberalismo. Argumenta que a maior parte dos Estados reagiu com uma forte desproporção, ao acionar medidas temporárias drásticas de Estado de Emergência que suspendem muitos direitos constitucionais garantidos normalmente. Parece quase que, no dizer de Agamben (ibid.), esgotado o terrorismo como causa de medidas de exceção, a deflagração de uma epidemia possa oferecer o pretexto ideal para ampliá-las além de todo limite. 0 outro fator, não menos preocupante, é o estado de medo que nos últimos anos foi evidentemente se difundindo nas consciências dos indivíduos e que se traduz em uma verdadeira necessidade de estados de pânico coletivo, para o qual a epidemia mais uma vez oferece o pretexto ideal. Assim, em um 
perverso círculo vicioso, a limitação da liberdade imposta pelos governos é aceita em nome de um desejo de segurança e de saúde pública que foi induzido pelos próprios governos que agora intervêm para satisfazê-lo.

Como referem Algebaile e Godinho de Oliveira (2020), a pandemia da covid19 é, sem dúvida, o evento contemporâneo que mais se aproxima dos cenários distópicos traçados anteriormente, não tanto pela gravidade ou facilidade de contágio da doença causada pelo vírus, mas especialmente pelo espaço, tempo, ritmo e escala em que se desenvolve, globalizando-se rapidamente e generalizando uma tragédia humana de forma transversal, mas diferenciada, que galga de forma eficiente todas as fronteiras modernas que eventualmente poderiam funcionar como barreiras à sua expansão, nomeadamente, as hierarquias econômicas entre nações, entre continentes e entre classes sociais,

implicando uma ocorrência mundial praticamente simultânea, que amplifica e socializa de forma imprevista os limites de seu enfrentamento, produzindo um quadro profundamente desconcertante, seja pela forma e rapidez com que produz a tragédia humana em larga escala, seja pela forma como revela os variados aspetos do despreparo mundial (não só dos países pobres!) para seu enfrentamento [...]. (p. 3)

A crise pandémica da covid19 apanhou-nos de surpresa, impondo, aos governos, às famílias e aos serviços públicos essenciais, uma pressão inesperada e desafios exigentes às formas de economia, de vida e de trabalho, provocando alterações de rotina profundas, de forma a debelar a crise sanitária e a expansão do coronavírus, mas sem efeito ainda contabilizado na capacidade de evitar a deflagração de uma crise capitalista, económica e social. Dada a natureza imprevisível do vírus e a sua expansão generalizada, difusa e aparentemente equitativa, muitos dizem que estamos na presença de um "choque simétrico", isto é, algo que afeta todos por igual (países e pessoas) e em que todos sofremos as consequências, independentemente do estatuto socioeconómico de cada um e do seu posicionamento na divisão social e espacial do trabalho. Recentemente, opiniões mais críticas, como Ferreira (2020), Harvey (2020), Davis (2020), têm dado mais atenção ao impacto desigual e pluriescalar do vírus nas sociedades e nos territórios. A desigualdade começa por se notar entre os países: enquanto as economias mais avançadas dispõem de mecanismos de mitigação dos impactos económicos - por exemplo, a atuação dos bancos centrais na injeção de liquidez nos mercados, que permita conter o pânico dos investidores e facilitar as condições de financiamento dos Estados (evitando que os juros da dívida pública disparem) - os países em desenvolvimento não têm a mesma sorte. Não estamos "todos no mesmo barco", nem "tudo vai ficar bem" para todos, e isso também se refletirá na profunda recessão sentida no pós-covid. Por outro lado, décadas de neoliberalismo e o mais recente período de austeridade posterior à crise capitalista 20082009 deixaram a população e os territórios totalmente expostos e mal preparados para enfrentar uma crise de saúde pública na escala do coronavírus (Harvey, 2020; Ferreira, 2020).

No caso de Portugal, no dia 18 de março de 2020, foi decretado o estado de emergência, através do decreto do Presidente da República n. 14-A/2020. No seguimento de normas derivadas da Organização Mundial de 
Saúde, que havia qualificado a situação como de emergência para a saúde pública ocasionada pela rápida proliferação da pandemia e da doença covid19, tornou-se imperiosa a promoção de medidas urgentes para assegurar não só o seu tratamento, mas, sobretudo, para prevenir que as cadeias de transmissão do vírus não evoluíssem. Assim, em resposta à pandemia, foi tomada uma série de medidas excecionais e temporárias, de caráter extraordinário e de restrição de direitos e liberdades, em especial no que respeita aos direitos de circulação e às liberdades económicas, em articulação com as autoridades europeias. Foi prioridade do governo português prevenir a doença, conter a pandemia, procurando salvar vidas e garantir que as cadeias de abastecimento fundamentais de bens e serviços essenciais continuassem a ser asseguradas. Com efeito, urgiu adotar as medidas que eram essenciais, adequadas e necessárias para, proporcionalmente, restringir determinados direitos que, mesmo constitucionais, poderiam pôr em risco o imperativo de salvar o bem maior que é a saúde pública e a vida da população portuguesa.

A democracia não poderá ser suspensa, numa sociedade aberta, onde o sentimento comunitário e de solidariedade é cada vez mais urgente. Assim, o presente decreto pretende proceder à execução do estado de emergência, de forma adequada e no estritamente necessário, a qual pressupõe a adoção de medidas com o intuito de conter a transmissão do vírus e conter a expansão da doença COVID-19. ${ }^{7}$

\section{"Mesmo em casa, a luta não faz quarentena"! "Ativismo de sofá" e novas práticas de luta urbana no período covid19}

\author{
Manifesto "Como se faz \\ quarentena sem casa?" \\ e negociação institucional
}

O conjunto de medidas temporárias e excecionais foi aplicado com respeito pelos limites constitucionais e legais, o que significa que, por um lado, as medidas limitaram-se ao estritamente necessário e, por outro, que os seus efeitos cessaram assim que retomada a normalidade. No que toca ao acesso ao direito à habitação, a ineficácia de garantir a aplicação das medidas de prevenção, como manter a higiene pessoal e garantir distanciamento e isolamento social, mostrou como a pandemia veio expor de forma dramática as contradições do modelo de produção capitalista de cidade e de habitação, bem como as desigualdades socioterritoriais que já vinham do pré-covid, designadamente, da década pós-crise capitalista 2008-2009. Como lavar as mãos se não há sequer sabão e acesso doméstico à água? Como pensar em isolamento social em casas sobrelotadas? Como fazer quarentena sem casa? Este foi o mote que permitiu, aos coletivos e MSU de defesa do direito à habitação, mobilizarem o imperativo biopolítico do isolamento e confinamento para defesa da vida e direito à saúde, a favor da afirmação do direito 
à habitação como direito humano. Recorrendo aos recursos desenvolvidos ao longo dos últimos anos, à aprendizagem e à memória coletivas dos atores sociais, capacidade de organização, mobilização e trabalho em rede, os coletivos e movimentos pré-covid souberam capitalizar o direito à habitação como direito humano pela dificuldade ao seu acesso e em condições de habitabilidade digna, que permitam o isolamento requerido pelas autoridades políticas de saúde, catapultando essa problemática para o topo da agenda social e política.

No fim de semana anterior à promulgação do estado de emergência, já a Associação Habita e o coletivo Stop Despejos tinham produzido um manifesto intitulado "Como se faz quarentena sem casa?", subscrito por mais de 60 associações e coletivos, incluindo a plataforma Morar em Lisboa. O referido manifesto deu origem a um abaixo-assinado que reuniu cerca de 3.000 assinaturas em poucos dias. 0 manifesto pedia: o fim imediato dos despejos; o realojamento imediato de todas as pessoas e famílias despejadas e dos que se encontravam a viver na rua; e a requisição de casas vazias, sejam elas apartamentos turísticos, de luxo ou municipais, para realojamentos de emergência. Além disso, pedia, também, a suspensão do pagamento das rendas das casas para todas as pessoas afetadas pela crise, a suspensão do pagamento dos créditos habitação e das hipotecas, a suspensão das rendas dos espaços sociais, como coletividades e associações, bem como a suspensão das rendas de pequenos comércios e de pequenas empresas afetadas pela crise.

Essa petição sensibilizou milhares de pessoas na sociedade civil e ajudou a catapultar, para a agenda pública, as contradições mais primárias inerentes à problemática do direito à habitação. Esse esforço coletivo, associado ao envio de diversos ofícios que a Associação dos Inquilinos Lisbonenses (associação centenária de defesa do inquilinato e que pertence ao Morar em Lisboa) produziu nessas semanas de março e que enviou ao senhor Primeiro-Ministro de Portugal, a todo o governo e aos grupos parlamentares, acabou por surtir efeito. Sugeria-se, tendo em conta a gravidade e a excecionalidade do momento covid19, que não só deveriam ser suspensos os despejos, como deveria ser decretada a suspensão da legislação do arrendamento no que respeita a prazos, que só deveriam começar a contar findo o período de contingência. Considerou-se que os senhorios não deviam poder invocar a denúncia ou a oposição à renovação de contrato de arrendamento durante o período de contingência. Por fim, defendeu-se, também, o diferimento do pagamento das prestações dos empréstimos para compra de habitação por parte do cidadão comum ou no caso da aquisição de propriedade para associações sociais, culturais, etc. Todas essas medidas como forma de proteção à morada de família enquanto perdurasse a situação de pandemia e quarentena.

A Assembleia da República acolheu com aprovação e com sentido de urgência algumas das propostas feitas, e o consenso do plenário levou a que o senhor presidente da República acabasse de promulgar, no dia 19 de março, a lei 1-A/2020 "Medidas excecionais e temporárias de resposta à situação epidemiológica provocada pelo coronavírus Sars-CoV-2 e da doença covid19", na qual se determina que sejam suspensas as ações de despejo, os procedimentos especiais de despejo e os processos para entrega do imóvel arrendado, quando o arrendatário possa ser colocado em situação de fragilidade por falta de habitação própria. 
Além disso, foi criado um regime extraordinário e transitório de proteção dos arrendatários, que determinava que, até à cessação das medidas de prevenção, contenção, mitigação e tratamento da infeção epidemiológica covid19, conforme determinada pela autoridade nacional de saúde pública, ficassem suspensas as denúncias de contratos de arrendamento habitacional e não habitacional (comercial e associativo) efetuadas pelo senhorio e a execução de hipoteca sobre imóvel que constitua habitação própria e permanente.

\section{"Resistir a partir de casa": visibilidade mediática e engajamento político e académico na produção de informação alternativa}

Para além da petição e do envio de memorandos (comunicação direta com o poder político), algumas estratégias mais criativas e inovadoras no sentido performativo foram levadas a cabo, uma vez que o direito à resistência e à circulação ou manifestação em espaço público tinha sido suspenso pelo estado de emergência. Como continuar a fazer resistência a partir de casa? Esta foi a questão primordial com a qual os movimentos sociais e coletivos se confrontavam desde então.

Gostaríamos de destacar quatro estratégias que nos parecem pertinentes nesse campo: a realização de assembleias em plataforma virtuais, o e-mail bombing, as redes locais de apoio mútuo e a Rede de Estudos de Habitação-Rede H.

No que toca à primeira estratégia, a associação Habita vinha já realizando, nos últimos meses, Assembleias de Resistência bimensais, nas quais se discutiam, com as vítimas dos despejos ou de ameaça de despejo, fragilidades, forças e estratégias de luta conjunta. 0 momento era crucial para empoderar as vítimas mais vulneráveis da segregação residencial e exclusão territorial e estimular uma socialização e coletivização dos problemas. 0 objetivo não era encontrar uma solução individual, mas que as soluções fossem pensadas e tomadas coletivamente, fortificando a consciência de classe. Como, neste momento, essas assembleias presenciais não são mais possíveis, devido à abolição do direito à resistência instaurado durante o estado de emergência, na impossibilidade de encontro presencial, estas passaram a realizar-se em plataformas digitais e redes sociais on-line.

Outra estratégia importante adotada foi o e-mail bombing. Os coletivos propuseram que no dia 8 de abril, às $12 \mathrm{~h}$, milhares de ativistas e cidadãos enviassem, simultaneamente, uma avalanche de mensagens eletrónicas com os mesmos destinatários, nesse caso órgãos de soberania política (Primeiro Ministro, Ministro da Habitação, Secretária de Estado da Habitação, entre outros), de forma a inundar as caixas de correio eletrónico desses órgãos com as suas demandas. No uso da Internet, o e-mail bombing é uma forma de abuso da rede, que consiste em enviar grandes volumes de e-mail para um endereço, na tentativa de sobrecarregar a caixa de correio. 0 envio em massa é uma estratégia comum, utilizada por organizações como a Amnistia Internacional. O objetivo consiste em enviar vários e-mails duplicados para o mesmo endereço de e-mail, não apenas para bloquear o serviço de envio e receção de e-mails, atuando de forma opositiva e confrontacional, mas como estratégia simbólica para alertar e acordar as autoridades políticas da necessidade de intervenção 
robusta no campo da habitação, nessa crise pandémica. Não se tem, contudo, uma noção do alcance mediático dessa campanha.

Uma outra estratégia de luta, mais colectivista e de bairro, é a formação de redes locais de apoio mútuo, destacando-se as cantinas solidárias, com as quais dezenas de ativistas dos coletivos mencionados colaboram atualmente. Esse tipo de estratégia social, que existia já numa rede de instituições de apoio social e centros comunitários, reforça-se agora em toda a cidade de Lisboa, com o aparecimento de refeitórios improvisados, mesmo muitas vezes nos espaços das associações, destinados ao fornecimento de refeições, para consumo no domicílio ou no refeitório, em especial a indivíduos e famílias em situação de vulnerabilidade socioeconómica. O localismo dessas redes de solidariedade e interajuda promove um modelo cooperativo de produção e consumo e não é desligado de uma intenção política e de acesso a um manifesto que permite também consciencialização de classe.

A última estratégia, a do engajamento político do cientista, sublinha a vertente de compromisso crítico e social de académicos com a definição de políticas, nomeadamente, a forma como a produção de conhecimento e sua validação pela comunidade científica tem concorrido para informar, legitimar ou contestar medidas políticas (Alves e Falanga, 2019). Fundada em fevereiro de 2020, a Rede H Rede Nacional de Estudos sobre Habitação ${ }^{8}$ reúne cerca de 60 académicos/as, ativistas e outros atores da sociedade civil, unidos pelo interesse no estudo do tema da habitação. Em meados de março, antes da declaração do estado de emergência, publicaram uma carta aberta aos governantes e à sociedade portuguesa, versando várias medidas urgentes a serem implementadas de forma a reforçar o direito à habitação. Essa carta aberta marca o início de um percurso de reflexão e participação ativa no debate sobre habitação em Portugal durante e depois da pandemia covid19, levado a cabo pela rede, embora esta já se tivesse formado desde junho 2019, na altura, procurando criar troca de experiência entre diversos projetos científicos versando sobre habitação, turismo e movimentos sociais.

Entenderam que as medidas aprovadas na altura da pandemia pelo Parlamento (como a suspensão dos despejos, dos efeitos das denúncias de contratos de arrendamento e da execução de hipotecas) e por algumas câmaras municipais (como a suspensão das desocupações do parque habitacional municipal) foram positivas, mas ainda insuficientes ante as necessidades sentidas. Antevendo um elevado risco de não cumprimento da Lei de Bases da Habitação e do Plano Nacional de Contingência covid19, bem como das várias circulares informativas provenientes da Direção-Geral da Saúde e do Ministério da Saúde, solicitaram a promulgação imediata de um conjunto de medidas dirigidas à habitação, designadamente: mobilizar os espaços disponíveis através de requisição civil, por exemplo, da indústria hoteleira, do alojamento local, habitações que pudessem ser temporariamente cedidas, para suprir o cumprimento de confinamento e de quarentena com vista a evitar riscos para a saúde individual, familiar e pública, devendo beneficiar, primeiramente, pessoas em situação de sem-abrigo, famílias a viver em condições de precariedade habitacional extrema ou sobrelotação, vítimas de violência doméstica ou de género, entre outros. Prorrogar automaticamente os contratos de arrendamento (habitacionais ou não) durante o período de 
emergência nacional, acrescido de período adequado para procura de nova habitação permanente e condigna, findo o período. Prevenir o aumento dos encargos com a habitação, através da redução ou suspensão dos pagamentos das rendas e das prestações de crédito das famílias que sofriam diminuição dos rendimentos. Proteger os pequenos proprietários cujas rendas constituem parte substancial da sua subsistência, com medidas de alívio fiscal e de apoio financeiro.

A Rede $\mathrm{H}$ possui dois objetivos principais que, durante o período pandémico, não só assessoraram e, através de método propositivo, apresentaram informação legitimadora ou contrastante das medidas políticas temporárias nessa fase, como reforçaram a pressão mediática junto aos órgãos políticos. 0 primeiro está relacionado com a investigação realizada no campo de estudos de habitação e o segundo com a aproximação dos estudos de habitação com o contexto não académico, político, social, etc. O primeiro objetivo, e que foi aquele que inicialmente esteve na génese do próprio coletivo, é o de desenvolver a colaboração interinstitucional dentro do campo de estudos de habitação. Para tal, facilita-se a criação de projetos e grupos de trabalho comuns, sendo as diferentes temáticas que os organizam e não a proveniência do cientista, professor ou investigador. Não só se estará a articular estudos em contextos territoriais diferentes, mas também a aproximar grupos e indivíduos com interesse de investigação similar, evitando a sobreposição dos estudos realizados. Garante-se, também, a partilha de resultados e dados - outputs de investigação, bases de dados trabalhados e até, possivelmente, dados brutos.
O segundo objetivo que preside à Rede $\mathrm{H}$, e que, de facto, se destacou no engajamento político e mediático na rede durante a crise pandémica tem que ver com a necessidade de potenciar a visibilidade dos estudos de habitação para fora do contexto académico e de outros contextos especificamente interessados no tema (p.e. ativismos, imobiliário). Nesse caso, a rede contribui para a deliberação pública através da participação ativa no debate público de medidas e políticas; facilita o acesso a jornalistas, políticos, técnicos e demais interessados, a estudos e resultados de investigação, através de um repositório organizado por temas-chave e com prioridade a material de acesso aberto; e estimula o debate público sobre habitação e o conhecimento necessário nesse campo.

Mas, sobretudo, a Rede $\mathrm{H}$ favorece a aproximação do mundo científico e do seu habitus ao campo prático do ativismo, o que terá sido também mobilizado pela participação de investigadores e professores membros da rede no ativismo nos últimos anos, com a produção de relatórios, pareceres, participação política e na consultadoria de partidos políticos e mesmo em vários órgãos da democracia institucional e sistema legal (ex. Assembleia Municipal de Lisboa, Comissão de Habitação e Ordenamento do Território do Parlamento, entre outros) e influenciando diretamente o meio institucional da democracia formal e representativa na adoção de medidas sociais para o direito à habitação. A aprendizagem coletiva cimentada por alguns dos seus membros, que conciliam o académico com o ativista, alimenta a vontade de a Rede pressionar o poder político e influenciar a tomada de medidas políticas legitimadas pelo conhecimento científico, 
baseadas em tomadas de decisão pública acertadas e legitimadas pela técnica e ciência. Assim, a produção de conhecimentos científicos alternativos para, além de fugirem ao status quo de um paradigma positivista e hegemónico de produção científica, alimentarem a intervenção cívica e práticas de cidadania ativa.

\section{Considerações finais}

Muito antes do Movimento Occupy, da globalização e do capitalismo financeirizado, já as cidades modernas se tinham tornado pontos territoriais centrais no auxílio do processo de acumulação de capital e na sempre renovada produção de desigualdades socioespaciais, ao sabor dos interesses hegemónicos do mercado urbano das mais-valias e (des)valorizações imobiliárias e fundiárias. Mas, simultaneamente, isso se verifica quando constatamos que as cidades sempre se afirmaram como espaços que aglutinam e unificam as forças de resistência anticapitalista e de irradiação de políticas revolucionárias, das quais correntes profundas de mudança social e política emergem. É na cidade, enquanto extraordinária produção social do espaço, que se confrontam, como numa arena entre frentes de batalha, tanto as forças hegemónicas e implacáveis do capitalismo que monopolizam os recursos urbanos e que ditam a qualidade e organização da vida urbana quotidiana; como as multidões que deste se refugiam e contra o qual se rebelam, construindo nos limites do capital, identidades, valores e modos de vida alternativos que desafiam a continuidade do projeto capitalista. Desde a Comuna de Paris, passando pelo Movimento Occupy em Wall Street e pelos protestos em
Londres, a teoria urbana crítica recente tem vindo a problematizar a busca de sentidos críticos e transformativos da diversidade de movimentos sociais (urbanos), distintos do sujeito revolucionário previsto pelo marxismo ortodoxo. Abraçando a cultura de base, horizontalidade e de bottom-up das lutas recentes, mas sem deixar de criticar os potenciais excessos do que poderá ser o avesso do centralismo e autoritarismo associado às formas políticas tradicionais de comunismo, Harvey (2012), por exemplo, reconhece o papel das cidades e da sua organização como espaços-alavanca mobilizadores da transformação crítica das sociedades em direção à justiça social e espacial e a um ambiente mais sustentável, não como finalidades, mas como meios e condições de transição anticapitalista e de reconstrução de um projeto pós-capitalista.

Assim, essa teoria proporciona um enquadramento de investigação-ação com implicações muito práticas para a definição de estratégias revolucionárias que, através da reconfiguração da urbanização e da vida nas cidades, ganhe uma organização com base geográfica, capaz de gerar um urbanismo revolucionário, como forma universal de revolução política. Tal como aconteceu na transição revolucionária do feudalismo para o capitalismo, é no aproveitamento dos espaços intersticiais que se podem iniciar movimentos sociais alternativos. Nesse aspeto, a adaptabilidade e a flexibilidade notórias do capitalismo proporcionam-nos um importante modelo, em face da dispersão, fragmentação e desunião das forças críticas. A revolução urbana tem de ser um movimento em toda a aceção da palavra. Se não puder mover-se entre, através e pelas diferentes esferas (tecnologias e formas organizacionais; relações sociais; disposições 
institucionais e administrativas; processos de produção e de trabalho; relações com a natureza; reprodução da vida quotidiana e conceções mentais do mundo), como diz Harvey (2010), acaba por fracassar. O reconhecimento dessa necessidade torna imperativo que se concebam alianças numa vasta gama de forças sociais representativas das diferentes esferas de atividade humana. A história variável e as evoluções do movimento anti ou por uma globalização alternativa desde o final da década de 1990 também sugerem que estamos numa fase muito especial e talvez radicalmente diferente de luta anticapitalista. 0 período da pandemia expôs que, apesar da sua fraca capacidade de mobilização, do seu caráter limitado e fugaz, a verdade é que não raras vezes os novos MSUs comportam inovação social e política, encetada por vanguardas poderosas, pois visam a mudanças "transformativas" e novas respostas que implicam transformação das relações de poder na cidade contemporânea.

A nova teoria dos movimentos sociais diz-nos que a forma e a intensidade da articulação do processo social das lutas urbanas por habitação na cidade com o processo que tem por base outras contradições da estrutura social revelam a capacidade de transformar, por meio dessas práticas, o conjunto das relações de classe ou, se quisermos, a sua eficácia própria enquanto MSU. E isto, não do ponto de vista da influência que as lutas urbanas podem ter sobre a mobilização política individual dos habitantes da cidade, mas, antes, em relação à convergência do movimento de práticas reivindicativas urbanas com as lutas sociais suscitadas por outros problemas sociais e políticos. A ligação dos MSUs à luta política propriamente dita parece ser a pedra de toque para apreciar a sua potencialidade revolucionária ou reformista, nomeadamente, a relação que permitem estabelecer entre a democracia participativa (da cidadania) e a democracia representativa (dos partidos políticos e das instituições). Para isso, urge associar a luta urbana - na qual são recorrentes diversos meios de expressão popular: petições, desobediência civil, performance em espaço público, iniciativas cidadãs, manifestações ofensivas, ocupações, autodefesa, etc. - à luta política institucionalizada, que afronte o desenvolvimento urbano desigual e injusto. Essa é uma conclusão importante que se retira junto da intervenção e do discurso dos atores sociais envolvidos nos MSUs nesta fase pandémica.

O surgimento de novas contradições sociais consideradas pela economia política marxista como secundárias (minorias várias, feminismo, ambiente, etc.) conduziu à necessidade de libertar o conceito de MSU da sua carga ideológica e da dependência tutelar do movimento operário, o que não representa necessariamente uma fraqueza, pois, ainda que se assista a uma multiplicação de pequenos grupos, muitas vezes, incapazes de se organizar, frequentemente demasiado radicais, a verdade é que essa desorganização pode ser uma condição de êxito no início de formação do movimento. Todavia, sendo contínuo, um MSU não pode existir sem forças sociais e instituições de enquadramento organizacional. À medida que os MSUs se vão expandindo e ganhando força política, à medida que se estruturam os seus programas de orientação ideológica e se consolidam as suas bases organizativas, a sua componente formal reforça-se, pelo que as conquistas alcançadas tendem a apresentar uma relação direta com o progressivo enquadramento institucional do movimento. Mesmo as comunidades contemporâneas 
que promovem a cidadania participativa e a democracia de proximidade não existem fora das determinantes estruturais das formações sociais. Nessa medida, para se oporem aos poderes hegemónicos capitalistas da ofensiva neoliberal em meio urbano, precisam de uma representação de si mesmas e de meios institucionais para ampliar a sua base social de participação e mobilização (Harvey, 2009).

Em rigor, trata-se de realçar a passagem do movimento de moradores de uma fase inicial de ações localizadas e espontâneas a uma outra fase caracterizada já por um projeto e um discurso de intervenção global na cidade, cujo impacto importa confrontar com as condições político-sociais que os envolveram e determinaram (Gallaher, 2016; Helbrecht, 2018; Sequera e Nofre, 2018). Essa ligação entre lutas urbanas e luta política, essa passagem progressiva de uma esfera para outra, é o ponto fundamental na dinâmica de transformação que os MSUs podem suscitar na ordem social dominante produzida pelo neoliberalismo urbano. Essa ligação é função do próprio processo de luta urbana, da clareza do seu programa político e ideológico, dos agentes que nela intervêm e da sua organização, das formas que toma o conflito concreto sobre o qual se debruça. Esse percurso verificou-se recentemente em Lisboa durante o período da covid19, pois, mesmo considerando a dinâmica de todas as frentes de ação urbana mais radicais de luta pelo direito à habitação (ocupações de casas devolutas e greve às rendas), está-se na presença de lutas urbanas que configuram agora um movimento social, de maior alargamento da sua base institucional e social. De facto, a sua breve duração, o seu caráter espontâneo, a natureza secundária e embrionária dos seus efeitos imediatos e a sua forma organizacional precária acabam por envolver um número não muito significativo de moradores. 0 peso do efémero e a falta de organização surgem como elementos inibidores da força transformadora que esses movimentos podem transportar.

Como refere Castells (2013), os MSUs pós-crise continuarão, de qualquer forma, a lutar, a debater, a evoluir e, eventualmente, a desaparecer, na sua forma atual de existir, assim como, no passado, todos os movimentos sociais históricos o fizeram também. E mesmo no caso improvável de se configurarem como novo ator político, partido ou outra forma de agência, cedo cessam a sua existência, por isso mesmo: porque a única questão relevante para avaliar o real significado de um movimento social é a que se detém na produtividade histórica e social da sua práxis e dos efeitos que esta produziu sobre os seus participantes enquanto pessoas e sociedade que procurou transformar.

Algebaile e Godinho de Oliveira (2020) destacam que a intensificação da investida neoliberal e das instabilidades e conflitos da pandemia decorrentes, a partir da crise capitalista, social e económica que se instalar no período pós-covid, torna ainda mais necessárias as indagações sobre as possibilidades, o conteúdo, as formas e a extensão das lutas anticapitalistas capazes de incidir de modo mais decisivo sobre o fim do capitalismo e de, ao mesmo tempo, constituir as bases objetivas e subjetivas da sua superação por relações econômicas, políticas e sociais de novo tipo.

É, sobretudo, no período presente de pandemia covid19 que as contradições da produção capitalista do espaço urbano ganham relevância e expõem de forma brutal as desigualdades extremas no acesso ao direito à 
habitação. Essa situação associada à narrativa do dever moral panótico de governo de si, através do lockdown forçado e obrigatório, de forma a respeitar o cumprimento das normas sanitárias das autoridades de saúde pública, evidenciam, ainda mais, a brutalidade dos casos de segregação residencial, despejos e injustiça espacial. Em Lisboa, as associações, coletivos e movimentos sociais de defesa do direito à habitação souberam capitalizar esses aspetos, ancorando a luta urbana na habitação como direito humano, essencial à vida, invertendo o imperativo biopolítico e conquistando, mesmo que temporariamente e de forma excecional, objetivos importantes, como a suspensão dos despejos, a suspensão do pagamento das hipotecas das casas, o realojamento dos mais vulneráveis em airbnb ou quartos de hotel, impondo, portanto, o direito à habitação ao direito à propriedade, o valor de uso ao valor de troca, abrindo precedentes que podem ser úteis na luta social pós-covid.

Ainda que conscientes que estas sejam medidas excecionais e temporárias, e que correspondam, portanto, a conquistas muito efémeras associadas ao Estado de Emergência gerado por essa crise pandémica, no horizonte pós-covid alguns vislumbram que essas políticas anticapitalistas tomadas por um Estado social robusto possam antecipar alguma mudança para um regime de transição pós-capitalista. Não nos esqueçamos, porém, que estas são medidas biopolíticas, tomadas num contexto de totalidade sistémica neoliberal, de forma a reproduzir os corpos e as massas da força de trabalho e de consumo. As medidas temporárias e excecionais tomadas durante a crise pandémica não revelam só a "bondade institucional" do governo neoliberal perante o imperativo de defender a sociedade como corpus necessário à reprodução capitalista, são, também, a expressão máxima do domínio biopolítico que gere o corpo social e territorial, como nos diz Bismarck (2020). Na tríade de Foucault (2008, 2010b), "sociedade, território, população", a saúde da população, dos territórios e das cidades, o certificar pela governamentalidade da possibilidade de manutenção de que as suas necessidades vitais e básicas sejam garantidas, afiguram-se, em verdade, como condição capital que interessa à gestão da economia e da finança do sistema capitalista hegemónico, no sentido de manter indefinidamente a sua capacidade de reprodução, garantindo, na sua reinvenção na crise pós-covid, novas formas de extração de mais-valia que estendam até ao mais ínfimo detalhe do tecido social, do quotidiano local, a acumulação por despossessão. Afinal, é preciso que algo mude para que tudo fique na mesma.

\section{[I] https://orcid.org/0000-0001-5281-4207}

Universidade de Lisboa, Instituto de Geografia e Ordenamento do Território, Centro de Estudos Geográficos. Lisboa, Portugal.

luis.mendes@campus.ul.pt 


\section{Agradecimento}

Este trabalho é financiado por fundos nacionais através da FCT - Fundação para a Ciência e a Tecnologia, I.P., no âmbito do projeto Hopes: HOusing PErspectives and Struggles Futures of housing movements, policies and dynamics in Lisbon and beyond (PTDC/GES-URB/28826/2017).

\section{Notas}

(1) http://moraremlisboa.org/

(2) http://habita.info/

(3) https://stopdespejos.wordpress.com/

(4) Ibid.

(5) http://habita.info/vitorias/

(6) Disponível em: https://dre.pt/home/-/dre/119397714/details/maximized

(7) Vide https://www.portugal.gov.pt/pt/gc22/comunicacao/documento?i=decreto-do-governoque-regulamenta-o-estado-de-emergencia-

(8) https://www.redehabitacao.pt/

\section{Referências}

AALBERS, M. B. (2008). The financialization of home and the mortgage market crisis. Competition \& Change, v. 12, n. 2, pp. 148-166.

(ed.) (2012). Subprime cities: the political economy of mortgage markets. Oxford, Wiley Blackwell.

(2016). The financialization of housing: a political economy approach. Londres, Routledge.

(2017). The Variegated Financialization of Housing. International Journal of Urban and Regional Research, v. 41, n. 4, pp. 542-554.

(2019). Financial geography III: The financialization of the city. Progress in Human Geography, https://doi.org/10.1177/0309132519853922

ACCORNERO, G.; HARB, M.; MAGALHÃES, A.; SANTOS, F.; SEMI, G.; SAMUEL, S.; TULUMELLO, S. (2020). "Stay Home Without a Home": Report from a webinar on the right to housing. Radical Housing Journal, v. 2, n. 1, pp. 197-201. 
AGAMBEN, G. (2010). Estado de excepção. Lisboa, Edições 70.

(2020). Lo stato d'eccezione provocato da un'emergenza immotivata. I/ Manifesto, 26 fevereiro. Disponível em: https://ilmanifesto.it/lo-stato-deccezione-provocato-da-unemergenzaimmotivata/. Acesso em: 2 maio 2020.

ALGEBAILE, E.; GODINHO DE OLIVEIRA, F. (2020). A superação do capitalismo em questão: com que prática, em qual direção? Espaço e Economia, v. 9, n. 17, DOI: 10.4000/espacoeconomia.11131.

ALVES, S. (2017). Requalificação e reabilitação do centro histórico do Porto. Scripta Nova. Revista Electrónica de Geografía y Ciencias Sociales, v. 21, n. 557, pp. 1-32.

ALVES, A.; FALANGA, R. (2019). (Des)encontros entre academia e política: conhecimento, engajamento e habitação em Portugal. Cidades, Comunidades e Territórios, n. 38, pp. 14-19.

BAPTISTA, L.; NOFRE, J.; JORGE, M. R. (2018). Mobilidade, cidade e turismo: pistas para analisar as transformações em curso no centro histórico de Lisboa. Sociologia: Revista da Faculdade de Letras da Universidade do Porto, número temático - Cidade, cultura e turismo: novos cruzamentos, pp. 14-32.

BARATA SALGUEIRO, T. (2017). Alojamentos Turísticos em Lisboa. Scripta Nova. Revista Electrónica de Geografía y Ciencias Sociales, v. 21, n. 578, pp. 1-43.

BARATA SALGUEIRO, T.; MENDES, L.; GUIMARÃES, P. (2017). "Tourism and urban changes: lessons from Lisbon". In: GRAVARY-BARBAS, M.; GUINAND, S. (eds.). Tourism and gentrification in contemporary metropolises: international perspectives. Londres, Routledge, pp. 255-275.

BISMARCK, P. (2020). Uma vida privada: pandemia e capitalismo. Revista Punkto, 15 de abril. Disponível em: https://www.revistapunkto.com/2020/04/uma-vida-privada-pandemia-e-capitalismo.html. Acesso em: 12 maio 2020.

BRADLEY, Q. (2014). The tenants' movement: resident involvement, community action and the contentious politics of housing. Londres, Routledge.

BRINGEL, B. (2015). Movimentos sociais e geopolítica da indignação: Brasil e Espanha em perspectiva comparada. Palestra proferida no Instituto de Ciências Sociais, 21 de janeiro. Lisboa.

BUTLER, J.; ATHANASIOU, A. (2013). Dispossession: the performative in the political. Cambridge, Polity Press.

CARVALHO, L.; CHAMUSCA, P.; FERNANDES, J.; PINTO, J. (2019). Gentrification in Porto: floating city users and internationally-driven urban change. Urban Geography, DOI: 10.1080/02723638.2019.1585139.

CASTELLS, M. (1973). Luttes Urbaines et Pouvoir Politique. Paris, Maspero.

(1983). The city and the grassroots: a cross-cultural theory of urban social movements. Los Angeles, University of California Press.

(2013). Redes de indignação e esperança. Movimentos sociais na era da internet. Lisboa, Fundação Calouste Gulbenkian.

CÓcOLA GANT, A. (2018). “Tourism gentrification”. In: LEES, L.; PHILLIPS, M. (eds.). Handbook of Gentrification Studies. Cheltenham and Northampton, Edward Elgar Publishing, pp. 281-293. 
CócolA GANT, A.; GAGO, A. (2019). Airbnb, buy-to-let investment and tourism-driven displacement: a case study in Lisbon. Environment and Planning A: Economy and Space, DOI: 10.1177/0308518X19869012.

COLOMB, C.; NOVY, J. (2016). Protest and Resistance in the Tourist City. Londres, Routledge.

DAVIS, M. (2020). Mike Davis on Coronavirus: "In a Plague Year". Jacobin Magazine, 20 de março. Disponível em: https://jacobinmag.com/2020/03/mike-davis-coronavirus-outbreak-capitalismleft-international-solidarity. Acesso em: 10 abril 2020.

ESTANQUE, E. (1999). Acção colectiva, comunidade e movimentos sociais: para um estudo dos movimentos de protesto público. Revista Crítica de Ciências Sociais, 55, pp. 85-111.

(2014). Rebeliões de classe média? Precariedade e movimentos sociais em Portugal e no Brasil (2011-2013). Revista Crítica de Ciências Sociais, n. 103, pp. 53-80.

FERREIRA, V. (2020). A pandemia e a desigualdade: estamos todos no mesmo barco? Ladrões de Bicicletas, 17 de abril. Disponível em: https://ladroesdebicicletas.blogspot.com/2020/04/ a-pandemia-e-desigualdade-estamos-todos_17.html?fbclid=IwAR0I81 wuEwnYm7_ ipISIIRaWrDzGw6I_UPczspBcoh_uUX3909QCrAT4K68. Acesso em: 18 abril 2020.

FONSECA, D. (2018). "The anti-austerity protest cicle in Portugal: The ambiguous relations between social movements and left-wing political parties". In: DAVID, I. (ed.). Crisis, austerity and transformation: how disciplinary neoliberalism is changing Portugal. Londres, Lexington.

FOUCAULT, M. (2008). Sociedade, território, população. São Paulo, Martins Fontes.

(2010a). Nascimento da biopolítica. Lisboa, Edições 70.

(2010b). Em defesa da sociedade. São Paulo, Martins Fontes.

GAGO, A. (2018). O Aluguer de curta duração e a gentrificação turística em Alfama, Lisboa. Tese de mestrado. Lisboa, Universidade de Lisboa.

GAGO, A.; COCOLA-GANT, A. (2019). "O alojamento local e a gentrificação turística em Alfama, Lisboa". In: SANTOS, A. C. (org.). A nova questão da habitação: uma abordagem de economia política. Lisboa, Conjuntura Actual.

GALLAHER, C. (2016). The politics of staying put. Filadélfia, Temple University Press.

HARVEY, D. (1985). The urbanization of capital. Blackwell, Oxford.

(2009). Cosmopolitanism and the geographies of freedom. Nova York, Columbia University Press.

(2010). The enigma of capital and the crisis of capitalism. Oxford, Oxford University Press.

(2012). Rebel cities: from the right to the city to the urban revolution. Londres, Verso.

(2014). Seventeen contradictions and the end of capitalism. Oxford, Oxford University Press.

(2020). Anti-Capitalist Politics in the Time of COVID-19. Jacobin Magazine, 20 de março. Disponível em https://jacobinmag.com/2020/03/david-harvey-coronavirus-political-economydisruptions Acedido a: 10 abr 2020.

HELBRECHT, I. (ed.) (2018). Gentrification and resistance: researching displacement processes and adaption strategies. Berlin, Springer. 
HUGHES, N. (2018). "Tourists go home": anti-tourism industry protest in Barcelona. Social Movement Studies, v. 17, n. 4, pp. 471-477.

KÖHLER, B.; WISSEN, M. (2003). Globalizing protest: urban conflicts and the global social movements. International Journal of Urban and Regional Research, v. 27, n. 4, pp. 942-951.

KÜNKEL, J.; MAYER, M. (eds.) (2012). Neoliberal urbanism and its contestations: crossing theoretical boundaries. Nova York, Palgrave Macmillan.

LESTEGÁS, I. (2019). Lisbon after the crisis: from credit-fuelled suburbanization to tourist-driven gentrification. International Journal of Urban and Regional Research, v. 43, n. 4, pp. 705-723.

LESTEGÁS, I.; SEIXAS, J.; GONZÁLEZ, R. (2019). Commodifying Lisbon: a study on the spatial concentration of short-term rentals. Social Sciences MDPI, v. 8, n. 33; doi:10.3390/socsci8020033.

MALET CALVO, D.; GAGO, A.; CócOlA-GANT, A. (2018). "Turismo, negocio inmobiliario y movimientos de resistencia en Lisboa, Portugal”. In: MILANO, C.; MANSILLA, J. A. (eds.). Ciudad de vacaciones. Conflictos urbanos en espacios turísticos. Barcelona, Pol·len edicions, sccl, pp. 121-154.

MANSILLA, J. (2018). No es turismofobia, es lucha de clases. Políticas urbanas, malestar social y turismo en un barrio de Barcelona. NODO, v. 23, n. 11, pp. 42-60.

MAYER, M. (2010). Social Movements in the (Post-)Neoliberal City. Civic City Cahier 1. Londres, Bedford Press.

MAYER, M.; THÖRN, C.; THÖRN, H. (eds.) (2016). Urban Uprisings. Challenging Neoliberal Urbanism in Europe. Londres, Palgrave Macmillan.

MENDES, L. (2008). Gentrificação e a cidade revanchista: que lugar para os movimentos sociais urbanos de resistência? Fórum Sociológico, 18, pp. 21-28.

(2016). Tourism gentrification: touristification as Lisbon's new urban frontier of gentrification. Lisboa, Stadslab and Academia Cidadã, 16th april. [mimeo].

(2017). Gentrificação turística em Lisboa: neoliberalismo, financeirização e urbanismo austeritário em tempos de pós-crise capitalista 2008-2009. Cadernos Metrópole, v. 19, n. 39, pp. 479-512.

(2018a). "Tourism gentrification in Lisbon: The panacea of touristification as a scenario of a post-capitalist crisis". In: DAVID, I. (eds.). Crisis, austerity and transformation: how disciplinary neoliberalism is changing Portugal. Londres, Lexington, pp. 25-48.

(2018b). Gentrification and the new urban social movements in times of post-capitalist crisis and austerity urbanism in Portugal. Arizona Journal of Hispanic Cultural Studies, v. 22, n. 1, pp. 199-215.

(2020). How can we quarantine without a home? Responses of activism and urban social movements in times of COVID-19 pandemic crisis in Lisbon. Tijdschrift voor Economische en Sociale Geografie, v. 111, n. 3, pp. 318-332.

MILANO, C.; NOVELLI, M.; CHEER, J. (2019). Overtourism and degrowth: a social movements perspective. Journal of Sustainable Tourism, v. 27, n. 12, pp. 1857-1875.

MILLER, B. (2000). Geography and Social Movements. Minneapolis, University of Minnesota Press.

MILLER, B.; NICHOLLS, W. (2013). Social movements in urban society: the city as a space of politicization. Urban Geography, v. 34, n. 4, pp. 452-473. 
MONTEZUMA, J.; MCGARRIGLE, J. (2018). What motivates international homebuyers? Investor to lifestyle 'migrants' in a tourist city. Tourism Geographies, DOI: 10.1080/14616688.2018.1470196.

MOURA, H. (2019). A construção de um problema público: A luta de coletivos, associações e instituições pelo direito à habitação nos bairros históricos e centrais de Lisboa. In: XVIII ENANPUR, 27 a 31 de maio, Natal.

NEL.LO, O. (2015). La Ciudad en Movimiento. Crisis Social y Respuesta Ciudadana. Madri, Díaz \& Pons.

NOFRE, J.; MARTINS, J. C.; VAZ, D.; FINA, R.; SEQUERA, J.; VALE, P. (2018). The "Pink Street" in Cais do Sodré: urban change and liminal governance in a nightlife district of Lisbon. Urban Research \& Practice. DOI: 10.1080/17535069.2018.1449010.

PAVEL, F. (2016). El Bairro Alto en Lisboa entre gentrificación, turistificación y derechos de la población. In: INTERNATIONAL CONFERENCE CONTESTED CITIES “FROM CONTESTED CITIES TO GLOBAL URBAN JUSTICE - CRITICAL DIALOGUES". Madri, 4-7 July.

(2017). Turismo e mercantilização da cidade. Revista espaços vividos e espaços construídos: estudos sobre a cidade, v. 5, n. 1, pp. 21-28.

(2020). Em que casa fico? Reflexões acerca do direito à cidade e à habitação em tempo de Covid19. Finisterra, v. 55, n. 114, pp. 203-206.

PEREIRA, S. M. (2018). "Lisboa: cidade, lazer, investimento. Reconfigurações do habitar". In: SEIXAS, J. (eds.). Futuros de Lisboa. Lisboa, Câmara Municipal de Lisboa, pp. 150-163.

PICKVANCE, C. (2003). From urban social movements to urban movements. International Journal of Urban and Regional Research, v. 27, n. 1, pp. 102-109.

QUEIRÓS, M.; ROQUE, A.; QUINTELA, P.; LUDOVICI, A.; VITORIANO, N. (2015). “Born in the blogosphere, staged in the streets: austerity and urban social movements in Lisbon". In: GUALINI, E.; MOURATO, J.; ALLEGRA, M. (eds.). Conflict in the City. Contested Urban Spaces and Local Democracy. Berlin, Jovis Berlag, pp. 197-216.

ROLNIK, R. (2015). Guerra dos Lugares. A colonização da terra e da moradia na Era das Finanças. São Paulo, Boitempo.

SASSEN, S. (2014). Expulsions: brutality and complexity in the global economy. Nova York, Harvard University Press.

SEIXAS, J.; TULUMELLO, S.; CORVELO, S.; DRAGO, A. (2015). Dinâmicas sociogeográficas e políticas na Área Metropolitana de Lisboa em tempos de crise e de austeridade. Cadernos Metrópole, v. 17, n. 34, pp. 371-399.

SEIXAS, J.; BRITO GUTERRES, A. (2018). Political evolution in the Lisbon of the digital era. Fast urban changes, slow institutional restructuring and growing civic pressures. Urban Research \& Practice, v. 12 , n. 1 , pp. 99-110.

SEIXAS, J.; TULUMELLO, S.; ALLEGRETTI, G. (2019). Lisboa em transição profunda e desequilibrada. Habitação, imobiliário e política urbana no sul da Europa e na era digital. Cadernos Metrópole, v. 21, n. 44 , pp. 221-251.

SEQUERA, J.; NOFRE, J. (2018). "Urban activism and touristification in Southern Europe: Barcelona, Madrid \& Lisbon". In: IBRAHIM, J.; ROBERTS, J. (eds.). Contemporary Left-Wing Activism Vol 2: Democracy, Participation and Dissent in a Global Context. Londres, Routledge. 
SEQUERA, J.; NOFRE, J. (2019). Touristification, transnational gentrification and urban change in Lisbon: The neighbourhood of Alfama. Urban Studies, https://doi.org/10.1177/0042098019883734

SOUSA SANTOS, B. (1994). Pela mão de Alice. O social e o político na pós-modernidade. Porto, Afrontamento.

(2011). Renovar a teoria crítica e reinventar a emancipação social. São Paulo, Boitempo. (2020). A cruel pedagogia do vírus. Coimbra, Almedina.

TULUMELLO, S. (2018). "Struggling against entrenched austerity". In: OTHENGRAFEN, F.; SERRAOS, K. (eds.). Urban resilience, changing economy and social trends. Coping with socio-economic consequences of the crisis in Athens, Greece. Hannover, DruckTeam, pp. 61-80.

WILSON, J.; TALLON, A. (2012). "Geographies of gentrification and tourism". In: WILSON, J. (ed.). The routledge handbook of tourism geographies. Londres, Routledge, pp. 103-112.

Texto recebido em 11/jun/2020

Texto aprovado em 6/ago/2020 